International Journal of Instruction e-ISSN: 1308-1470 • www.e-iji.net
July $2018 \bullet$ Vol.11, No.3

p-ISSN: 1694-609X

pp. 419-432

Received: 18/12/2017

Revision: 04/04/2018

Accepted: 09/04/2018

\title{
The Relationship between Teacher Candidates' Views of the Nature of Science and Their Problem Solving Skills
}

\author{
İjlal Ocak \\ Assoc. Prof., Afyon Kocatepe University, Turkey,iocak@aku.edu.tr
}

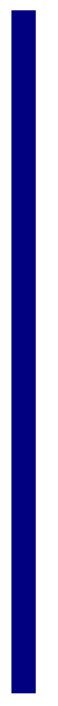

\begin{abstract}
The aim of this research is to examine the teacher candidates' views of the nature of science and their problem-solving skills in terms of various variables and, the relationship between them. 'Science-Technology-Society Scale (VOSTS)' developed by Aikenhead, Ryan \& Fleming (1989) and adapted by Ar1 (2010) through choosing 22 items (VOSTS-TR) and 'Problem Solving Inventory (PSI)' developed by Heppner \& Peterson (1982) and adapted by Şahin, Şahin \& Heppner (1993) were used as data collection instruments. While teacher candidates' views differed in the sub-dimension of the VOSTS-TR, their level of problem solving skills was found to be medium and high. According to two-way ANOVA results, the interaction of problem solving skills between gender does not create a significant difference on teacher candidates' views of nature of science and its characteristic features of scientific information sub-dimension. However, the interaction of problem solving skills between educational stage that they will serve create a significant differences on teacher candidates' views of nature of science. Teacher candidates' views of the nature of science were significantly predicted by their problem solving skills. In conclusion, the teacher candidates' views of the nature of science are not at a sufficient level and their views of the nature of science affected by problem solving skills.
\end{abstract}

Keywords: nature of science, problem solving, teacher candidate, teacher education, teaching

\section{INTRODUCTION}

There is no universally accepted definition of science literacy (Roberts, 2007; NRC, 2007). According to Gabel (1976), science literacy may exist in different forms and degrees and the nature of science is under the first dimension of science literacy. While there is no universal conceptualization of the nature of science (NOS) (Kang, Scharmann, \& Noh, 2005), Lederman (1992) said that NOS typically refers to the epistemology of science, science as a way of knowing, or the values and beliefs inherent to scientific knowledge and its development. A concise description of NOS is often debated among the scholars (Matthews 1994) and NOS representations are as dynamic

Citation: Ocak, İ. (2018). The Relationship between Teacher Candidates' Views of the Nature of Science and Their Problem Solving Skills. International Journal of Instruction, 11(3), 419-432. https://doi.org/10.12973/iji.2018.11329a 
as the knowledge and enterprise of science itself. In describing NOS from epistemological and associated sociological perspectives, Ryan \& Aikenhead (1992) include the meaning of science, assumptions, values, conceptual inventions, method, consensus making, and the characteristics of the knowledge produced. Lederman, Wade, and Bell (1998) suggested that these values and assumptions include independence of thought, creativity, tentativeness, being empirically based, subjectivity, testability, and cultural and social embeddedness.

Holbrook \& Rannikmae (2007) said that the nature of science education is clearly portrayed as more than an understanding of the nature of science, or acquisition of scientific ideas. The nature of science education puts the learning of the nature of science into an educational framework. Researchers turned their attention to teaching the nature of science and teachers' conceptions as data emerged, indicating that students did not possess what were considered as adequate conceptions of NOS. A teacher must possess adequate knowledge of what he/she is attempting to communicate to students (Lederman 1992) because teachers who teach scientific literacy and the nature of science shape their students' views, too. When the literature in Turkey and abroad are examined, it is seen that the views of teachers and students in different grades on NOS are either insufficient or wrong (Solomon, Scott \& Duveen 1996; Palmquist \& Finley 1997, Abd-El Khalick \& BouJaoude 1997; Khishfe \& Abd-El Khalick 2002; Çelikdemir, 2006; Küçük 2006; Liu \& Lederman 2007; Buaraphan \& Sung-Ong 2009; Çil 2010; Doğan 2010).

Problem solving is defined as the self-directed cognitive-behavioral process by which an individual, couple, or group attempts to identify or discover effective solutions for specific problem encountered in everyday living as it occurs in the natural environment, (D'Zurilla \& Goldfried, 1971). According to Hepner \& Baker (1997) problem-solving refers to the cognitive, affective and behavioral processes and to the particular set of skills people employ in order to find solutions for the challenges of everyday life. Heppner \& Peterson (1982) categorized three kinds of attitude towards problem-solving, specifically: 1) Problem-solving confidence: whether one possesses confidence when faced with problems; 2) Approach/avoidance style: applying an initiative approach or avoidance strategies when faced with problems; 3) Personal control: whether one puts into practice after a well-organized design when faced with problems.

The most important goal of science education is to educate person who are science literate. Understanding the nature of science is also an important aspect of science literacy. According to Lin and Chiu. (2002) promoting students' problem-solving ability, especially conceptual, has long been considered one of the most important goals of science education. Also, Shomes (1995) stated that as important as problem-solving ability, understanding the nature of science has been regarded as one of the basic requirements for scientific literacy. Both understanding the nature of science and problem-solving skills for science literacy are more important for enhancing true scientific literacy. For this reason, this study has been established to determine the relationship between teacher candidates' view of the nature of science and their problem solving skills. It was also aimed to test the effect of the interaction between gender and 
problem solving skills, and the educational stage that they will serve and problem solving skills, on the nature of science.

\section{Research Questions}

1. What is distribution of the teacher candidates' views of NOS (the definition of science, the characteristic features of the scientist, the social structure of the scientific information, and the characteristic features of the scientific information)?

2. What is the level of teacher candidates' problem solving skills (PSS)?

3. Is there a statistically significant difference in teacher candidates' views of in terms of their PSS?

4. Does the interaction of PSS with gender create a significant difference in teacher candidates' views of NOS?

5. Does the interaction of problem-solving success with educational stage that they will serve create a significant difference in teacher candidates' views of NOS?

6. Is there a statistically significant relationship between teacher candidates' views of NOS and PSS?

7. Are teacher candidate' views of NOS significantly predicted by their PSS?

\section{METHOD}

The research that investigates the teacher candidates' views of NOS, PSS and the relationship between these two variables employs correlational survey method. Survey design provides a quantitative or numeric description of trends, attitudes, or opinions of a population by studying a sample of that population. From sample results, the researcher generalizes or makes claims about the population. In an experiment, investigators may also identify a sample and generalize to a population (Creswell, 2009; Karasar, 2012).

\section{Sampling}

The population of the research includes undergraduate and pedagogical formation certificate program students at Afyon Kocatepe University. The sample includes 366 teacher candidate studying primary school math, science, pre-school, class teaching and pedagogical formation certificate program students from biology, physics, chemistry, visual arts and history. Teacher candidates are 255 women and 111 males. 78 of the teacher candidate will serve in primary school, 119 in secondary school and 169 in high school education.

\section{Data Collection}

Teacher candidates' views of NOS were collected through "Views of ScienceTechnology-Society Scale" (VOSTS) that was experimentally developed by Aikenhead, Ryan \& Fleming (1989) and adapted by Arı (2010) through choosing 22 items (VOSTSTR). The items of (VOSTS-TR) are placed within four sub-dimensions: science (1 item), the characteristic features of scientists (4 items), social structure of scientific information (5 items) and the nature of scientific information (12 items). No reliability 
studies were conducted for VOSTS-TR. Because, Aikenhead and Ryan (1992) stated that it is inappropriate to speak about the reliability and validity of an empirically developed instrument in the traditional sense because reliability and validity of an empirically developed instrument arise from the qualitative paradigm. Besides, Problem Solving Inventory (PSI) developed by Heppner \& Peterson (1982) to identify students' problem solving skills and adapted by Şahin, Şahin \& Heppner (1993) was used. The scale of PSI internal consistency reliability was determined by the calculation of Cronbach's coefficient. The alpha value for the scale is .706. Nunnally \& Bernstein (1994) recommend reliabilities of 0.70 or better for basic research and Cronbach (1951) indicates that a value higher than 0.50 was considered a satisfactory level of internal consistency.

\section{Data Analysis}

Problem Solving Inventory (PSI) was scored according to Savaşır \& Şahin (1997) and VOSTS-TR was scored as indicated in Bradford, Rubba \& Harkness (1995). The data from both scales were transferred to the computer. While mean and standard deviation were used as descriptive statistics, t-test, one-way ANOVA, two-way ANOVA, correlation test and simple linear regression analysis were used to analyze the relationship between the scores obtained from two scales.

\section{FINDINGS}

\section{Research Question 1}

What is the distribution of the teacher candidates' views of NOS (the definition of the science, the characteristic features of the scientist, the social structure of the scientific information, and the characteristic features of the scientific information)? The findings related to this problem are given in Table- 1 below.

Table 1

Distribution of Teacher Candidates' Views of Definition of Science (1.Sub-dimension of VOSTS-TR)

\begin{tabular}{llllllll}
\hline Item (Definition of Science) & 0 & 1 & 2 & 3 & $\bar{X}$ & Result \\
\hline $\begin{array}{llllllll}\text { 1. Defining science is difficult because } \\
\text { science is complex and does many things. }\end{array}$ & $\mathrm{f}$ & 18 & 10 & 207 & 131 & & \\
\cline { 2 - 6 } But MAINLY science is: & $\%$ & 4.9 & 2.7 & 56.6 & 35.8 & & \multirow{2}{*}{$\begin{array}{c}2.32 \\
\text { Bucc }\end{array}$}
\end{tabular}

0: No idea (NI), 1:1-1.66: Insufficient (Ins), 2:1.67-2.33: Acceptable (Acc), 3:2.33-4: Realistic (R) (The same coding and abbreviations were used in the other items.)

The distribution of the teacher candidates' views of the definition of science subdimension of VOSTS-TR is acceptable. 
Table 2

Distribution of Teacher Candidates' Views of Characteristic Features of Scientists (2. Sub-dimension of VOSTS-TR)

\begin{tabular}{|c|c|c|c|c|c|c|}
\hline Item (Characteristic Features of Scientists) & 0 & 1 & 2 & 3 & $\bar{X}$ & Result \\
\hline 2. The best scientists are always very open-minded, logical, unbiased $f$ & 7 & 57 & 24 & 278 & \multirow[b]{2}{*}{2,56} & \multirow[b]{2}{*}{$\mathrm{R}$} \\
\hline $\begin{array}{l}\text { and objective in their work. These personal characteristics are needed } \% \\
\text { for doing the best science. }\end{array}$ & 1.9 & 15.6 & $6 . .6$ & 76.0 & & \\
\hline \multirow{2}{*}{$\begin{array}{l}\text { 3. Scientists have practically no family life or social life because they } \frac{\mathrm{f}}{\%} \\
\text { need to be so deeply involved in their work. }\end{array}$} & 15 & 55 & 40 & 256 & \multirow{2}{*}{-2.46} & \multirow[b]{2}{*}{$\mathrm{R}$} \\
\hline & 4.1 & 15.0 & 10.9 & 69.9 & & \\
\hline 4. There are many more women scientists today than there used to be. $f$ & 13 & 134 & 74 & 145 & \multirow[b]{2}{*}{1.95} & \multirow[b]{2}{*}{ Acc } \\
\hline $\begin{array}{l}\text { This will make a difference to the scientific discoveries which are } \\
\text { made. Scientific discoveries made by women will tend to be different } \% \\
\text { than those made by men. }\end{array}$ & 3.6 & 36.6 & & 39. & & \\
\hline lef & 23 & 37 & 169 & 137 & \multirow[b]{2}{*}{-2.14} & \\
\hline his is: & 6.3 & 10. & 46.2 & 37. & & \\
\hline
\end{tabular}

According to Table-2, the distribution of the teacher candidates' views of the characteristic features of scientists sub-dimension of VOSTS-TR is generally realistic.

Table 3

Distribution of Teacher Candidates' Views of Social Structure of Scientific Information (3. Sub-dimension of VOSTS-TR)

\begin{tabular}{|c|c|c|c|c|c|c|c|}
\hline Item (Social Structure of Scientific Information) & & 0 & 1 & 2 & 3 & $\bar{X}$ & Result \\
\hline \multirow{2}{*}{$\begin{array}{l}\text { 6. When a new scientific theory is proposed, scientists must decide } \\
\text { whether to accept it or not. Their decision is based objectively on the } \\
\text { facts that support the theory. Their decision is not influenced by their } \\
\text { subjective feelings or by personal motives. }\end{array}$} & f & 32 & 111 & 184 & 39 & \multirow[b]{2}{*}{1.62} & \multirow[b]{2}{*}{ Ins } \\
\hline & $\%$ & 8.7 & 30.3 & 50.3 & 10.7 & & \\
\hline \multirow{2}{*}{$\begin{array}{l}\text { 7. Scientists compete for research funds and for who will be the first to } \\
\text { make a discovery. Sometimes fierce competition causes scientists to } \\
\text { act in secrecy, lift ideas from other scientists, and lobby for money. In } \\
\text { other words, sometimes scientists ignore the ideals of science (ideals } \\
\text { such as sharing results, honesty, independence, etc.). }\end{array}$} & $\mathrm{f}$ & 37 & 162 & 151 & 16 & \multirow{2}{*}{1.39} & \multirow{2}{*}{ Ins } \\
\hline & $\%$ & 10.1 & 44.3 & 41.3 & 4.4 & & \\
\hline \multirow{2}{*}{$\begin{array}{l}\text { 8. When scientists disagree on an issue (for example, whether or not } \\
\text { low-level radiation is harmful), they disagree mostly because they do } \\
\text { not have all the facts. Such scientific opinion has NOTHING to do } \\
\text { with moral values (right or wrong conduct) or with personal motives } \\
\text { (personal recognition, pleasing employers, or pleasing funding } \\
\text { agencies). }\end{array}$} & $\mathrm{f}$ & 25 & 108 & 159 & 74 & \multirow[b]{2}{*}{1.77} & \multirow[b]{2}{*}{ Acc } \\
\hline & $\%$ & 6.8 & 29.5 & 43.4 & 20.2 & & \\
\hline \multirow{2}{*}{$\begin{array}{l}\text { 9. A scientist may play tennis, go to parties, or attend conferences with } \\
\text { other people. Because these social contacts can influence the } \\
\text { scientist's work, these social contacts can influence the content of the } \\
\text { scientific knowledge he or she discovers. }\end{array}$} & f & 28 & 70 & 144 & 124 & \multirow[b]{2}{*}{1.99} & \multirow[b]{2}{*}{ Acc } \\
\hline & $\%$ & 7.7 & 19.1 & 39.3 & 33.9 & & \\
\hline \multirow{2}{*}{$\begin{array}{l}\text { 10. Scientists trained in different countries have different ways of } \\
\text { looking at a scientific problem. This means that a country's education } \\
\text { system or culture can influence the conclusions which scientists reach. }\end{array}$} & $\mathrm{t}$ & 14 & 4 & 121 & 227 & \multirow[t]{2}{*}{2.53} & \multirow[t]{2}{*}{$\mathrm{R}$} \\
\hline & & & & & & & \\
\hline
\end{tabular}

According to Table-3, the distribution of the teacher candidates' views of the characteristic features of scientists sub-dimension of VOSTS-TR is either insufficient or acceptable, except item 10. 
Table 4

Distribution of Teacher Candidates' Views of Characteristic Features of Scientific Information (4.Sub-dimension of VOSTS-TR)

\begin{tabular}{|c|c|c|c|c|c|c|}
\hline Item (Characteristic Features of Scientific Information) & 0 & 1 & 2 & 3 & $\bar{X}$ & $\begin{array}{l}\text { Resul } \\
\mathrm{t}\end{array}$ \\
\hline \multirow{2}{*}{$\begin{array}{l}\text { 11. Many scientific models used in research laboratories (such } \mathrm{f} \\
\text { as the model of heat, the neuron, DNA, or the atom) are copies } \frac{}{\%} \\
\text { of reality. }\end{array}$} & 19 & 265 & 52 & 30 & \multirow{2}{*}{1.25} & \multirow{2}{*}{ Ins } \\
\hline & 5.2 & 2.4 & 14.2 & 8.2 & & \\
\hline \multirow{2}{*}{$\begin{array}{l}\text { 12. When scientists classify something (for example, a plant } \\
\text { according to its species, an element according to the periodic } \\
\text { table, energy according to its source, or a star according to its } \\
\text { size), scientists are classifying nature according to the way \% } \\
\text { nature really is; any other way would simply be wrong. }\end{array}$} & 24 & 113 & 56 & 173 & \multirow[b]{2}{*}{2.03} & \multirow[b]{2}{*}{ Acc } \\
\hline & 6.6 & 30.9 & 15.3 & 47.3 & & \\
\hline \multirow{2}{*}{$\begin{array}{l}\text { 13. Even when scientific investigations are done correctly, the } \mathrm{f} \\
\text { knowledge that scientists discover from those investigations } \frac{}{\%} \\
\text { may change in the future. }\end{array}$} & 22 & 50 & 1 & 293 & \multirow{2}{*}{2.54} & \multirow{2}{*}{$\mathrm{R}$} \\
\hline & 6.0 & 13.7 & 0.3 & 80.1 & & \\
\hline \multirow{2}{*}{$\begin{array}{l}\text { 14. Scientific ideas develop from hypotheses to theories, and } \frac{\mathrm{f}}{\%} \\
\text { finally, if they are good enough, to being scientific laws. }\end{array}$} & 22 & 312 & 3 & 29 & \multirow{2}{*}{1.10} & \multirow{2}{*}{ Ins } \\
\hline & .0 & 2 & .08 & 7.9 & & \\
\hline \multirow{2}{*}{$\begin{array}{l}\text { 15. When developing new theories or laws, scientists need to } \mathrm{f} \\
\text { make certain assumptions about nature (for example, matter is } \\
\text { made up of atoms). These assumptions must be true in order } \% \\
\text { for science to progress properly. }\end{array}$} & 17 & 184 & 94 & 1 & \multirow[b]{2}{*}{1.59} & \multirow[b]{2}{*}{ Ins } \\
\hline & 4.6 & 50.3 & 25.7 & 19.4 & & \\
\hline \multirow{2}{*}{$\begin{array}{l}\text { 16. Good scientific theories explain observations well. But } \frac{\mathrm{f}}{\%} \\
\text { good theories are also simple rather than complex. }\end{array}$} & 46 & 122 & 119 & 79 & \multirow{2}{*}{.63} & \multirow{2}{*}{ Ins } \\
\hline & 12.6 & 33.3 & 32.5 & 21.6 & & \\
\hline \multirow{2}{*}{$\begin{array}{l}\text { 17. When scientists investigate, it is said that they follow the } \frac{\mathrm{f}}{\%} \\
\text { scientific method. The scientific method is: }\end{array}$} & 33 & 233 & 87 & 13 & \multirow{2}{*}{1.21} & \multirow{2}{*}{ Ins } \\
\hline & 9.0 & 63.7 & 23.8 & & & \\
\hline \multirow{2}{*}{$\begin{array}{l}\text { 18. Scientific discoveries occur as a result of a series of } \mathrm{f} \\
\text { investigations, each one building on an earlier one, and each } \\
\text { one leading logically to the next one, until the discovery is } \% \\
\text { made. }\end{array}$} & 22 & 89 & 60 & 195 & \multirow[b]{2}{*}{2.16} & \multirow[b]{2}{*}{ Acc } \\
\hline & 0 & 3 & & 53.3 & & \\
\hline \multirow{2}{*}{$\begin{array}{l}\text { 19. Scientists publish the findings of their research in scientific } \mathrm{f} \\
\text { journals. When they write an article for the journals, they } \\
\text { organize the report in a very logical and regular way. }\end{array}$} & 32 & 50 & 60 & 224 & \multirow{2}{*}{2.30} & \multirow{2}{*}{ Acc } \\
\hline & 8.7 & 1 & 16.4 & 61.2 & & \\
\hline \multirow{2}{*}{$\begin{array}{l}\text { 20. Scientists should NOT make errors in their work because } \frac{\mathrm{f}}{\%} \\
\text { these errors slow the advance of science. }\end{array}$} & 8 & 107 & 113 & 138 & \multirow{2}{*}{4} & \multirow{2}{*}{ Acc } \\
\hline & 2.2 & & & & & \\
\hline \multirow{2}{*}{$\begin{array}{l}\text { 21. If scientists find that people working with asbestos have } \mathrm{f} \\
\text { twice as much chance of getting lung cancer as the average } \\
\text { person, this must mean that asbestos causes lung cancer. }\end{array}$} & 62 & 112 & - & 192 & \multirow[b]{2}{*}{1.87} & \multirow[b]{2}{*}{ Acc } \\
\hline & 16.9 & 3 & - & 52.5 & & \\
\hline & 39 & 141 & 1 & 125 & & \\
\hline $\begin{array}{l}\text { very different points of view (for example, } \mathrm{H}+\text { causes chemists } \\
\text { to think of acidity and physicists to think oI protons). This } \% \\
\text { makes it difficult for scientists in different fields to understand } \\
\text { each other's work. }\end{array}$ & & & 16.7 & 34.2 & 1.74 & A \\
\hline
\end{tabular}

According to Table-4, the distribution of the teacher candidates' views of the characteristic features of scientific information sub-dimension of VOSTS-TR is either insufficient or acceptable, except item 13. 


\section{Research Question 2}

The findings related to "What is level of teacher candidates' (PSS)" question are given in Table- 5 below.

Table 5

The Distribution of Level of Teacher Candidates' PSS

\begin{tabular}{lll}
\hline Level & $\mathrm{N}$ & $\%$ \\
\hline Low & - & - \\
\hline Intermediate & 218 & 59.6 \\
\hline High & 148 & 40.4 \\
\hline Total & 366 & 100 \\
\hline
\end{tabular}

According to Table-5, 59.6 percent of the teacher candidates are in intermediate level while the rest is in high in terms of their PSS.

\section{Research Question 3}

Is there a statistically significant difference in teacher candidates' views of NOS in terms of their level of PSS? Findings related to this question are given below in Table- 6 .

Table 6

Independent Sample T-test Results for Teacher Candidates' Views of NOS in terms of Level of Problem Solving Skills (PSS)

\begin{tabular}{|c|c|c|c|c|c|c|c|}
\hline & $P S S$ & $\mathrm{~N}$ & $\mathrm{X}$ & Ss & sd & $\mathrm{t}$ & $\mathrm{p}$ \\
\hline \multirow{2}{*}{ Definition of science } & Intermediate & 218 & 2.12 & .71 & \multirow{2}{*}{364} & - & \multirow{2}{*}{$.001 *$} \\
\hline & High & 148 & 2.38 & .71 & & 3.35 & \\
\hline \multirow{2}{*}{$\begin{array}{l}\text { Characteristic features of } \\
\text { the scientist }\end{array}$} & Intermediate & 218 & 8.89 & 2.06 & \multirow{2}{*}{364} & - & \multirow{2}{*}{$.005 *$} \\
\hline & High & 148 & 9.49 & 1.83 & & 2.82 & \\
\hline \multirow{2}{*}{$\begin{array}{l}\text { Social structure of the } \\
\text { scientific information }\end{array}$} & Intermediate & 218 & 9.28 & 2.01 & \multirow{2}{*}{364} & \multirow{2}{*}{-.42} & \multirow{2}{*}{.672} \\
\hline & High & 148 & 9.37 & 1.92 & & & \\
\hline \multirow{2}{*}{$\begin{array}{l}\text { Characteristic features of } \\
\text { the scientific information }\end{array}$} & Intermediate & 218 & 21.32 & 4.31 & \multirow{2}{*}{364} & & \multirow{2}{*}{.282} \\
\hline & High & 148 & 21.80 & 3.94 & & 1.07 & \\
\hline \multirow{2}{*}{ Overall } & Intermediate & 218 & 41.64 & 6.10 & \multirow{2}{*}{364} & - & \multirow{2}{*}{$.02 *$} \\
\hline & High & 148 & 43.06 & 5.70 & & 2.23 & \\
\hline
\end{tabular}

$* \mathrm{p}<.05$

In terms of teacher candidates' problem solving levels, there is a statistically significant difference between the two groups (intermediate and low) in their overall features and definition of science and characteristic features of the scientist sub-dimensions. On the other hand, the difference is not significant in other two sub-dimensions.

\section{Research Question -4}

Does the interaction of PSS with gender create a significant difference on teacher candidates' views of NOS? Findings related to this question are given in Table-7 below. 
Table 7

Two-way ANOVA Result for The Interaction Effect of PSS with Gender on Teacher Candidates' Views of NOS

\begin{tabular}{lllllll}
\hline Variables & NOS & $\begin{array}{l}\text { Sum of } \\
\text { Squares }\end{array}$ & df & $\begin{array}{l}\text { Mean of } \\
\text { Squares }\end{array}$ & F & p \\
\hline PSS*Gender & Definition of science & 1.137 & 1 & 1.137 & 2.216 & .137 \\
\cline { 2 - 7 } & Characteristic features of the scientist & 3.085 & 1 & 3.085 & 0.816 & .367 \\
\cline { 2 - 7 } & Social structure of the scientific information & 5.556 & 1 & 5.556 & 1.416 & .235 \\
\cline { 2 - 8 } & $\begin{array}{l}\text { Characteristic features of the scientific } \\
\text { information }\end{array}$ & 14.641 & 1 & 14.641 & 0.86 & .354 \\
& Overall & 11.296 & 1 & 11.296 & .329 & .567 \\
\hline
\end{tabular}

According to the two-way ANOVA results, the interaction of PSS between gender does not create a significant difference on teacher candidates' views of NOS (Definition of science, the characteristic features of the scientist, the social structure of the scientific information, the characteristic features of the scientific information)

\section{Research Question -5}

Does the interaction of PSS with educational stage that they will serve (primary, secondary and high school) create a significant difference in teacher candidates' views of NOS? The findings related to this question are given in Table- 8 below.

Table 8

Two-way ANOVA for the Iinteraction Effect of PSS with the Educational Stage That They Will Serve on Teacher Candidates' Views of NOS

\begin{tabular}{|c|c|c|c|c|c|c|c|c|}
\hline Variables & NOS & $\begin{array}{l}\text { Sum of } \\
\text { Squares }\end{array}$ & $\mathrm{df}$ & $\begin{array}{l}\text { Mean of } \\
\text { Squares }\end{array}$ & $\mathrm{F}$ & $\mathrm{p}$ & $\begin{array}{l}\text { Eta } \\
\text { Squared }\end{array}$ & Difference \\
\hline \multirow{5}{*}{$\begin{array}{l}\text { PSS*The } \\
\text { educational } \\
\text { stage that } \\
\text { they will } \\
\text { serve }\end{array}$} & Definition of science & .067 & 2 & .034 & .065 & .937 & & \\
\hline & $\begin{array}{l}\text { Characteristic features of the } \\
\text { scientist }\end{array}$ & 19.667 & 2 & 9.833 & 2.553 & .079 & & \\
\hline & $\begin{array}{l}\text { Social structure of the scientific } \\
\text { information }\end{array}$ & .916 & 2 & .458 & .121 & .886 & & \\
\hline & $\begin{array}{l}\text { Characteristic features of the } \\
\text { scientific information }\end{array}$ & 125.29 & 2 & 62.554 & 3.676 & $.026^{*}$ & .020 & \\
\hline & Overall & 231.919 & 2 & 115.959 & 3.337 & $.035^{*}$ & .018 & $2-3$ \\
\hline
\end{tabular}

$* \mathrm{p}<.05$ (the educational stage that they will serve, 1: primary school, 2; secondary school, 3: high school)

According to two-way ANOVA results, the interaction of PSS between educational stage that they will serve create a significant difference on teacher candidates' views of NOS and its characteristic features of scientific information sub-dimension. As indicated in Table 8, there is a significant difference in favor of the high school educational stage between the high school educational stage and the secondary school educational stage.

\section{Research Question -6}

Is there a statistically significant relationship between teacher candidates' views of NOS and PSS?

The findings related to this question are given in Table-9 below. 
Table 9

Correlation between Teacher Candidates' Views of NOS and PSS

\begin{tabular}{llll}
\hline & & PSS & NOS \\
\hline \multirow{3}{*}{ PSS } & Pearson Correlation & 1 & $.195^{* *}$ \\
& Sig. (2-tailed) & & .000 \\
& $\mathrm{~N}$ & 366 & 366 \\
\hline
\end{tabular}

As stated in Table-9, there is a statistically significant relationship between teacher candidates' views of NOS and PSS. According to the correlation coefficient, the relationship between these two variables is positive and low

\section{Research Question -7}

Are teacher candidate' views of NOS significantly predicted by their PSS? The findings related to this question are given in Table-10 below.

Table 10

Regression Analysis Results for PSS as a Predictor of Teacher Candidates' Views of NOS

\begin{tabular}{|c|c|c|c|c|c|}
\hline & Sum of Squares & $\mathrm{df}$ & Mean Square & $\mathrm{F}$ & $\mathrm{p}$ \\
\hline Regression & 3546.313 & 1 & 3546.313 & \multirow[t]{3}{*}{14.333} & \multirow[t]{3}{*}{.000} \\
\hline Residual Constant & 90059.340 & 364 & 247.416 & & \\
\hline Total & 93605.653 & 365 & & & \\
\hline
\end{tabular}

As indicated in Table-10 above, according to simple linear regression analysis that was carried out to test how PSI scores predict VOSTS-TR scores, there is a statistically significance relationship between PSS and views of NOS results $\left(\mathrm{R}=.195 ; \mathrm{R}^{2}=.038\right)$; PSS is a significant predictor of views of $\operatorname{NOS}(\mathrm{F} 1-364=14.33 \mathrm{p}<.05)$. The coefficient of determination is 0.038 ; therefore, about $3.8 \%$ of the variation in views of NOS is explained by problem solving skill. Accordingly, teacher candidates' PSI scores have a statistically significant effect on their VOSTS-TR scores.

\section{DISCUSSION}

This study investigated teacher candidates' views of NOS (definition of science, the characteristic features of the scientist, the social structure of the scientific information, the characteristic features of the scientific information), their PSS, whether PSS brings a significant difference in views of NOS, interaction of PSS with gender and PSS with educational stage that they will serve on, teacher candidates' views of NOS and finally the relationship between teacher candidates' views of NOS and their PSS.

When sub-dimensions of VOSTS-TR are examined, the results are at acceptable level in definition of science sub-dimension. Similarly, Saraç \& Capellaro (2015) tell that teachers and teacher candidates do not agree on the definition of science and they have acceptable ideas. However, Doğan-Bora (2005), Arı (2010) and Çınar \& Köksal (2013) find that participants have unrealistic ideas on the definition of science. In VOSTS-TR, teacher candidates mostly have realistic ideas on features of scientists sub-dimension, which shows similar results with Doğan-Bora (2005), Aslan (2009) and Saraç \& Capellaro (2015). On the other hand, Yenice, Özden and Balc1 (2015) state that teacher 
candidates of science and class have both realistic and insufficient ideas. Participants have insufficient and acceptable ideas on social structure of scientific information. Teacher candidates have insufficient ideas especially on "this cruel competition sometimes results in scientists' behaving secretly" item. Beşli (2008) thinks that this result is somewhat caused by the nature of the item itself. Saraç \& Capellaro (2015) explain that teachers have acceptable ideas on this issue. Teacher candidates mostly have acceptable and insufficient ideas on characteristic features of scientific information sub-dimension of VOSTS-TR. This result is similar with some other national and international studies' results (Lederman, 1992; Abd-El-Khalick \& Boujaoude 1997; Moss, Abrams \& Robb 2001; Taşar 2003; Doğan-Bora, 2005; Çelikdemir 2006; Beşli 2008; Doğan, Akçay, Kaya \& Öcal 2008; Aslan 2009; Aslan, Yalçın \& Taşar, 2009).

In terms of the teacher candidates' PSS, 60 percent of them are at intermediate level while the rest is at high level according to problem-solving inventory scores (PSI). This result is similar with the results obtained by Sezen (2007) that indicates teacher candidates' PSS are at intermediate level while it is contradictory with the findings of Karabacak et al. (2015) who explains that teacher candidates' PSS is low.

While there is a statistically significant difference in teacher candidates' view of overall features NOS and the two sub-dimensions, definition of the science and characteristic features of scientists, in terms of the level of their PSS, the difference in other subdimensions of is not significant.

According to the two-way ANOVA results, the interaction of PSS with gender does not create a significant difference on teacher candidates' views of NOS. The literature does not include any findings on the same issue; however, the study by Bora \& Çakıroğlu (2006) indicates that female students have a higher realistic view on NOS than the male students do.

The interaction of PSS with educational stage that they will serve creates a significant difference on teacher candidates' views of NOS. The significant difference is only in characteristic features of scientific information sub-dimension and there is a significant difference in favor of the high school educational stage between the high school educational stage and the secondary school educational stage. In their study that investigates teacher candidates' views of NOS and their subject field, Çelik \& Karataş (2016) explain that views of NOS differ significantly in terms of the subject fields teacher candidates study. The teacher candidates of the science teaching especially have a more positive view than the other fields do. Similarly, Arslan, Bora \& Çakıroğlu (2006) indicate that students' views of NOS differ in terms of their departments.

There is a significant correlation between teacher candidates' scores from PSI and VOSTS-TR. The correlation coefficient indicates a low-level positive relationship. The result of the simple linear regression analysis that has been carried out to examine how teacher candidates' PSI scores predict their VOSTS-TR score reveals that there is a significant relationship between PSS and NOS scores $(\mathrm{R}=.195 ; \mathrm{R} 2=.038)$, so teacher candidate' views of NOS was significantly predicted by their PSS. The literature does not provide a study that examines the relationship between NOS and PSS. However, there are studies on scientific literacy and different variables. Mbajırgu \& Ali (2003) 
retain that success in biology is a significant predictor of scientific literacy. In short, understanding NOS does not affect their academic success. Günüşen \& Üstün (2011) find an intermediate level significant relationship between nursing students' focus of control and problem solving skills. Kourmousi et al. (2016) find out a relationship between all sub-dimensions of problem solving inventory and Multi-dimensional Focus of Control Scale and Rosenberg Self-esteem Scale (RSES). Dündar (2009) identifies a positive relationship between students' problem solving skills and personality overall fit and social and personal fit that are the sub-scales. When the students' fit levels increase in the mentioned personality features, their problem solving skills also increase.

In this study that examines teacher candidates' views of NOS in terms of some variables, it is seen that their views in the overall scale and its sub-dimensions are mostly insufficient or acceptable. Teacher candidates' views of the topic should be developed. Besides, using approaches that increase PSS of teacher candidates in teacher training might be effective in their understanding NOS. In their experimental research, Çelik \& Bayrakçeken (2006) investigate how using Science-Technology-Society approach grounded within scientific questioning for a semester change teacher candidates' views of NOS and the results tell that their views have changed significantly. Akerson et al. (2000) explain that approaches based on open reflective activities are more effective in developing participants' views of NOS. Lederman (2001) organizes an intervention in which class teachers' inclusion of NOS into their teaching at class has been facilitated. There are four factors, namely information on NOS, content knowledge, pedagogic knowledge and will on teaching NOS. Those participants who have had strong will and developed a good view on NOS have been more successful.

As a result, in teacher-training programs, it is observed that developing professional development curricula that will lead to one-by-one teaching might be used as an effective approach besides the education to develop teacher candidates' views of NOS (Palmquist \& Finley, 1997; Pomeroy, 1993).

According to the results of the research, teacher candidates' views of the nature of science are either acceptable or insufficient. It is important for teachers to have positive ideas on nature of science to raise students who understand the nature of science. So, it is necessary to include nature of science in teacher education programs and in-service trainings of teachers. Also, teachers candidates' problem solving skills has an effect on their views of the nature of science, teaching methods which can promote students' problem solving skills should be included more to raise individuals who have scientific thoughts. That the teacher candidates' abilities on the nature of science and problem solving are at the expected rate is also closely connected with the education they had in their previous degree. Especially, it should be conducted activities to foster adequate ideas on nature of science and to have effective problem solving skills in previous degrees. This research is conducted on preservice teachers. However, conducting this research on teachers in charge can contribute to science, itself.

\section{REFERENCES}

Abd-El-Khalick, F., \& BouJaoude, S. (1997). An exploratory study of the knowledge base for science teaching. Journal of Research in Science Teaching, 34/7, 673-699. 
Aikenhead, G. \& Ryan, G. (1992) The development of a new instrument: 'Views of ScienceTechnology-Society' (Vosts). Science Education, 76/5, 477-491.

Akerson, V. L., Abd-El-Khalick, F., \& Lederman, N. G. (2000). Influence of a reflective explicit activity-based approach on elementary teachers' conceptions of nature of science. Journal of Research in Science Teaching, 37/4, 295-317.

Arı, Ü. (2010). Fen bilgisi öğretmen adaylarının ve sınıf öğretmen adaylarının bilimin doğası hakkındaki görüşlerinin incelenmesi. (Unpublished Master Thesis). Firat Üniversitesi, Elazığ.

Arslan, O., Doğan-Bora, N., \& Çakıroğlu, J. (2006). The view points of high school students about scientific knowledge. Paper presented at the 7th National Science Education Assembly. Gazi Education Faculty. Turkey.

Aslan, O. (2009). Fen ve teknoloji ögretmenlerinin bilimin doğası hakkındaki görüşleri ve bu görüşlerin sinıf uygulamalarına yansımaları. (Unpublished Doctoral Dissertation.). Gazi Üniversitesi, Ankara.

Aslan, O., Yalçın, N., \& Taşar, M. F. (2009). Fen ve Teknoloji öğretmenlerinin bilimin doğası hakkındaki görüşleri. Journal of Kirsehir Education Faculty, 10/3, 1-8.

Beşli, B. (2008). Fen bilgisi öğretmen adaylarının bilim tarihinden kesitler incelemelerinin bilimin doğası hakkındaki görüşlerine etkisi.. Unpublished mMaster Thesis.Abant İzzet Baysal Üniversites, Bolu.

Bradford, C. S., Rubba, P. A., \& Harkness, W. L. (1995). Views about sciencetechnology-society interactions held by college students in general education physics and STS courses. Science Education, 79/4, 355-373.

Buaraphan, K., \& Sung-Ong, S. (2009). Thai pre-service science teachers' conceptions of the nature of science. Asia-Pacific Forum on Science Learning and Teaching, 10/1, 1-22.

Çelik, S., \& Bayrakçeken, S. (2006). The effect of a 'science, sechnology and Ssociety' course on prospective teachers' conceptions of the nature of science. Research in Science \& Technological Education, 24/2, 255-273.

Çelik, S., \& Karataş, F. Ö. (2016). Öğretmen adaylarının bilimin doğasına yönelik anlayışları ile öğrenim gördükleri alanlar arasındaki ilişki. Kastamonu Üniversitesi Kastamonu Eğitim Dergisi. 23/2, 755-772.

Çelikdemir, M. (2006). Examining middle school students' understanding of the nature of science. (Unpublished Master Thesis). Middle East Technical University, Ankara.

Çil, E. (2010). Bilimin doğasının kavramsal değişim pedagojisi ve doğrudan yansıtıcı yaklaşım ile ögretilmesi: Iş̧1k Ünitesi Örneği. (Unpublished Doctoral Dissertation). Karadeniz Teknik Üniversitesi, Trabzon.

Cronbach, L. J. (1951). Coefficient alpha and the internal structure of tests. Psychometrika, 16/3, 297-334.

Doğan -Bora, N. (2005). Türkiye genelinde ortaöğretim fen branşl öğretmen ve ögrencilerinin bilimin doğası üzerine görüşlerinin araştırılması. (Unpublished Doctoral Dissertation). Gazi Üniversitesi,. Ankara. 
Doğan, N. (2010). Farklı liselerde okuyan 11. sınıf öğrencilerinin bilimin doğası hakkındaki bakış açılarının karşıllaştırılması. Gazi Eğitim Fakültesi Dergisi, 30/2, 533-560.

Dündar, S. (2009). Üniversite öğrencilerinin kişilik özellikleri ile problem çözme becerileri arasındaki ilişkinin incelenmesi. Dokuz Eylül Üniversitesi Üniversitesi İktisadi ve İdari Bilimler Fakültesi Dergisi, 24/2, 139-150.

D'zurilla, T. J., \& Goldfried, M. R. (1971). Problem solving and behavior modification. Journal of Abnormal Psychology, 78/1, 107-126.

Gabel, L. L. (1976). The development of a model to determine perceptions of scientific literacy (Unpublished Doctoral Dissertation), The Ohio State University. Ohio.

Günüşen, N. P., \& Üstün, B. (2011). Hemşirelik öğrencilerinin problem çözme beceri düzeyleri ile kontrol odağı arasındaki ilişki. Dokuz Eylül Üniversitesi Hemşirelik Yüksekokulu Elektronik Dergisi, 4/2, 72-77.

Nunnally, J. C., \& Bernstein, I. H. (1994). Psychometric theory (3rd ed.). New. York; McGraw-Hill.

Heppner, P. P., \& Baker, C. E. (1997). Applications of the problem solving inventory. Measurement and Evaluation in Counseling and Development. 29, 229-241.

Heppner, P. P., \& Petersen, C. H. (1982). The development and implications of a personal problem-solving inventory. Journal of Counseling Psychology, 29/1, 66-75

Johnston, A. T. (2001). A conceptual change analysis of the nature of science conceptions: The deep roots and entangled vines of a conceptual ecology. (Unpublished Doctoral Dissertation), The University of Utah, Utah

Kang, S., Scharmann, L. C., \& Noh, T. (2005). Examining students' views of the nature of science: Results from Korean 6th, 8th, and 10th graders. Science Education, 89/2, 314-334.

Karabacak, K., Nalbant, D., \& Topçuoğlu, P. (2015). Examination of teacher candidates' problem solving skills according to several variables. Procedia-Social and Behavioral Sciences, 174, 3063-3071.

Kaya, O. N., Doğan, A., \& Öcal, E. (2008). Turkish elementary school students' images of scientists. Eurasian Journal of Educational Research, 32, 83-100.

Khishfe, R., \& Abd-El-Khalick, F. (2002). Influence of explicit and reflective versus implicit inquiry-oriented instruction on sixth graders' views of nature of science. Journal of Research in Science Teaching, 39/7, 551-578.

Kourmousi, N., Xythali, V., Theologitou, M., \& Koutras, V. (2016). Validity and reliability of the problem solving inventory (psi) in a nationwide sample of greek Educators. Social Sciences, 5/2, 2-11.

Küçük, M. (2006). Bilimin doğasını ilköğretim 7. sinıf öğrencilerine öğretmeye yönelik bir çalışma. (Unpublished Doctoral Dissertation), Karadeniz Teknik Üniversitesi, Trabzon.

Lederman, N. G., Schwartz, R. S., Abd-El-Khalick, F., \& Bell, R. L. (2001). Pre-service teachers' understanding and teaching of nature of science: An intervention study. Canadian Journal of Math, Science \& Technology Education, 1/2, 135-160.

Lederman, N. G. (1992). Students' and teachers' conceptions of the nature of science: A review of the research. Journal of Research in Science Teaching, 29(4), 331-359. 
Lin, H. S., \& Chiu, H. L. (2004). Student understanding of the nature of science and their problem-solving strategies. International Journal of Science Education, 26/1, 101-112.

Liu, S. Y., \& Lederman, N. G. (2007). Exploring prospective teachers' worldviews and conceptions of nature of science. International Journal of Science Education, 29/10, 12811307.

Matthews, M.R. (1994). Science teaching: The role history and philosophy of science. New York: Routledge.

Mbajiorgu, N. M., \& Ali, A. (2003). Relationship between STS approach, scientific literacy, and achievement in biology. Science Education, 87/1, 31-39.

Moss, D. M., Abrams, E. D., \& Robb, J. (2001). Examining student conceptions of the nature of science. International Journal of Science Education, 23, 771-790.

National Research Council (NRC) (1996). National science education standards. Washington, DC: National Academic Press.

National Research Council. (2007). Taking science to school: Learning and teaching science in grades $K-8$. Washington, DC: National Academies Press.

Palmquist, B. C., \& Finley, F. N. (1997). Preservice teachers' views of the nature of science during a postbaccalaureate science teaching program. Journal of Research in Science Teaching, 34/6, 595-615.

Pomeroy, D. (1993). Implications of teachers' beliefs about the nature of science: Com

parison of the beliefs of scientists, secondary science teachers, and elementary teachers. Science Education, 77/3, 261-278.

Roberts, D. A. (2007). Scientific literacy/science literacy. Handbook of Research on Science Education, 1, 120-144.

Ryan, A. G., \& Aikenhead, G. S. (1992). Students' preconceptions about the epistemology of science. Science Education, 76/6, 559-580.

Saraç, E., \& Cappellaro, E. (2015). Sınıf öğretmenleri ve sınıf öğretmeni adaylarının bilimin doğasına ilişkin görüşleri. Mediterranean Journal of Humanities, 2, 331-349

Savaşır, I., Şahin, N.H. (1997). Bilişsel-davranışçı terapilerde değerlendirme: Sık kullanılan ölçekler, Ankara: Türk Psikologları Derneği Yayınları.

Shamos, M. (1995). The myth of scientific literacy. New Brunswick, NJ: Rutgers University Press.

Solomon, J., Scott, L., \& Duveen, J. (1996). Large-scale exploration of pupils' understanding of the nature of science. Science Education, 80/5, 493-508.

Taşar, M. F. (2003). Teaching history and the nature of science in science teacher education programs. Pamukkale Üniversitesi Eğitim Fakültesi Dergisi, 1/13, 30-42.

Yenice, N., Özden, B., \& Balcı, C. (2015). Fen bilgisi ve sınıf öğretmeni adaylarının bilimin doğasına yönelik görüşlerinin incelenmesi. Erzincan Üniversitesi Eğitim Fakültesi Dergisi, 17/1, 237-281. 